\title{
The potential of interleukin-37 as an effective therapeutic agent in asthma
}

Lina Zhang ${ }^{1,2+}$, Jie Zhang ${ }^{1+}$ and Peng Gao ${ }^{1 *}$ (i)

\begin{abstract}
Interleukin (IL)-37 belongs to the IL-1 cytokine family. It binds to IL-18Ra and recruits the orphan decoy IL-1R8. Emerging evidence shows that IL-37 is a key player in the regulation of inflammation, cellular differentiation, and proliferation. Altered IL-37 expression has been demonstrated in many inflammatory disease conditions, including asthma. In rheumatoid arthritis, IL-37 is involved in the regulation of proliferation, production of inflammatory mediators, and activation of inflammatory cells. Furthermore, this cytokine acts as a negative regulator of inflammation in inflammatory bowel disease. Similarly, IL-37 also appears to suppress allergic inflammation in asthma. In a murine model of asthma, local administration of IL-37 markedly reduced the degree of inflammatory cell infiltration and airway hyper-responsiveness. IL-37 has also been shown to be involved in a number of aspects of allergic inflammation, such as eosinophil and neutrophil recruitment, as well as inhibition of Th1/Th2/Th17 inflammatory mediators. However, the exact molecular mechanisms underlying the function of IL-37 in human asthma have yet to be fully elucidated. This review describes the current evidence regarding the role of IL-37 in the pathophysiology of asthma and evaluates both the potential of IL-37 as a biomarker for airway inflammation and a therapeutic target for the treatment of asthma.
\end{abstract}

Keywords: Interleukin-37, Asthma, Inflammation, Airway hyper-responsiveness, Leukocytes

\section{Background}

Interleukin (IL)-37 was first described using in silico research in 2000, and increasing evidence has recently demonstrated that IL-37 has profound immunoregulatory functions [1-4]. These include cell proliferation, differentiation, suppression of acquired immunity, and limiting of innate inflammation (Fig. 1). IL-37 is a member of the IL-1 cytokine family that binds to IL-18R $\alpha$, which prevents it from binding IL-18 [5]. To date, 11 members have been identified that belong to the IL-1 family. Seven of those components (IL-1 $\alpha$, IL-1 $\beta$, IL-18, IL-33, IL-36 $\alpha$,

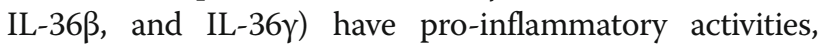
while there are four antagonists, including IL-1R antagonist, IL-36R antagonist, IL-37, and IL-38 [6]. The only member of the IL- 1 family where simian and murine homologues remain undiscovered is IL-37 [3, 7]. In humans, the IL-37 gene is located on chromosome 2 next to genes encoding 8 other members of the IL- 1 family. Five splice

\footnotetext{
* Correspondence: gaopeng1234@sina.com

${ }^{\dagger}$ Equal contributors

${ }^{1}$ Department of Respiratory Medicine, The Second Hospital of Jilin University, Changchun, Jilin, China

Full list of author information is available at the end of the article
}

transcript variants encode distinct isoforms of IL-37 (IL$37 \mathrm{a}-\mathrm{e})[1-4,8]$. IL-37b is the largest among the isotypes, and has 5 of the 6 exons $[9,10]$.

In the last decade, research has extensively demonstrated functions of IL-37 in both the innate and adaptive immune system. IL-37 suppresses the production of proinflammatory cytokines such as TNF- $\alpha$, IL- $1 \alpha$, IL-1 $\beta$, IL-6, G-CSF and GM-CSF from human blood LPS-stimulated monocytes [3, 11]. IL-37 can also reduce neutrophil infiltration into the lung [12] and monocyte infiltration following myocardial infarction [13]. Furthermore, it decreases dendritic cell (DC) activation and has a suppressive action in adaptive immunity [14]. Therefore, the main function of IL-37 is believed to be the reduction of excessive inflammation in both the adaptive and innate immune system through means of negative feedback [15].

IL-37 can exert its anti-inflammatory effects in both intracellular and extracellular conditions. After synthesis, one third of the IL-37b precursor is cleaved intracellularly and then translocated to the nucleus. This process is likely to be associated with $\operatorname{Smad} 3[3,16]$. On the other hand, cells transfected with IL-37 release an IL-37 


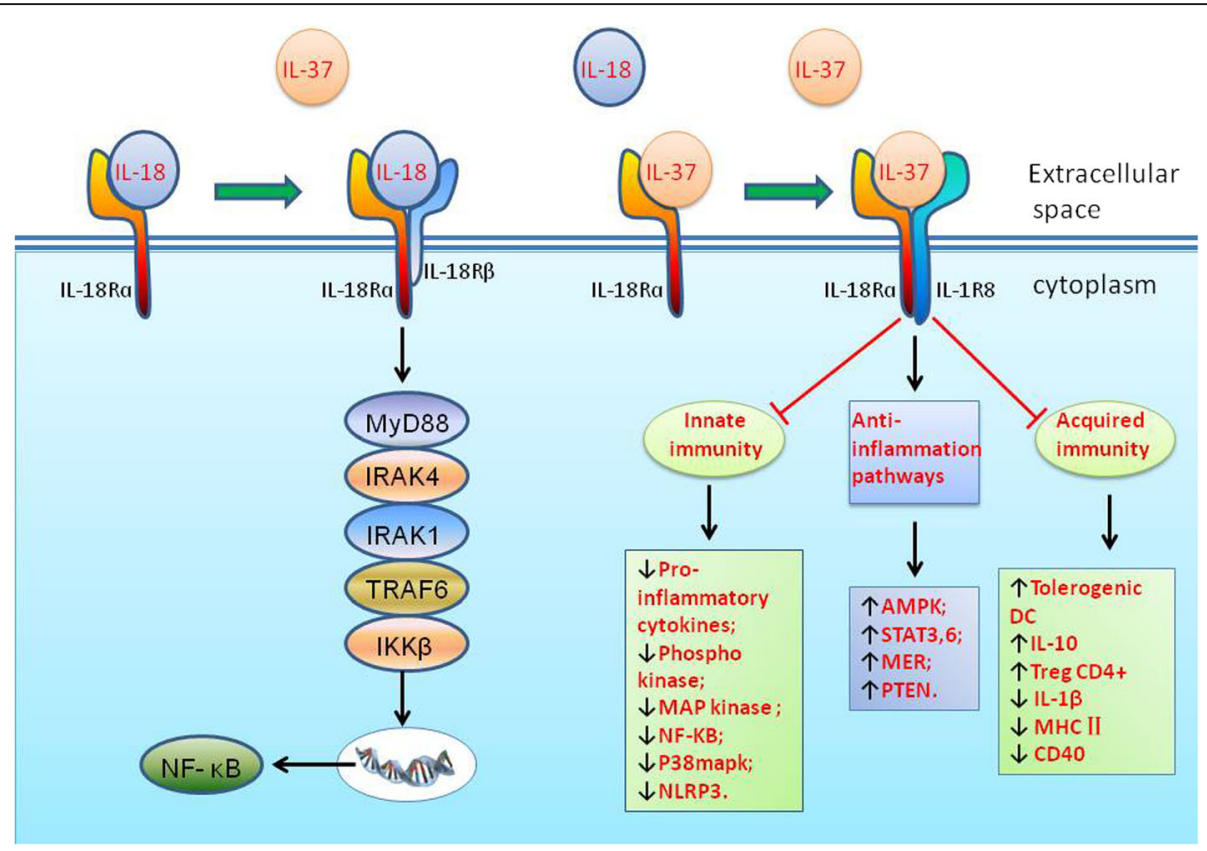

Fig. $1 \mathrm{IL}-37$ binding and signal transduction. IL-37 binds to IL-18Ra instead of IL-18 and recruits the orphan decoy IL-1R8, which leads to suppression of innate and acquired immunity, as well as augmentation of anti-inflammatory pathway, instead of activation of the IL-18 pathway. Adapted from Novick (2013) [61] and Dinarello (2016) [62]

precursor after LPS stimulation, which is independent of caspase-1 cleavage at D20 [17]. Extracellular IL-37 executes its anti-inflammatory effects by preventing IL-18R $\alpha$ from adhering to IL-18 and recruiting the orphan decoy IL-1R8 to the IL-18R $\alpha /$ IL-37/ IL-1R8 complex (Fig. 1) $[11,18,19]$. Neutralizing antibodies against IL-37 can enhance production of pro-inflammatory cytokines when it is either administered in vitro or in vivo $[17,20]$.

In recent decades, research activity focusing on IL-37 has increased rapidly. This might be due to the long list of diverse functions demonstrated by IL-37, and its active role in the physiopathology of multiple diseases (Table 1) including rheumatoid arthritis (RA), inflammatory bowel disease (IBD), and asthma. This present review summarizes the published literature on the functions and mechanisms of IL-37 in both humans and experimental models, and explores its role in the pathophysiology of asthma.

\section{IL-37 expression under inflammatory conditions}

IL-37 is expressed by a wide range of different tissue and cell types under normal physiological conditions. Cells and tissues that express IL-37 include human blood monocytes, plasma cells, synovial cells, tissue macrophages, tonsillar B cells, epithelial cells (skin and intestine), neoplastic cells, and kidney cells [3]. The level of IL-37 was markedly augmented at $24 \mathrm{~h}$ and $72 \mathrm{~h}$ in human IL-37-expressing transgenic mice (hIL-37tg mice) after spinal cord injury, while it was barely detectable under normal conditions [21]. The extracellular concentration of IL-37 is aberrantly expressed in a number of inflammatory diseases in humans. Increased levels of IL-37 have been detected in plasma and PBMCs from HIV-1-infected subjects compared to noninfected individuals [22]. Similar results were reported when the serum and synovial fluid of patients with RA was examined, and serum from patients with Graves' disease also has increased levels of IL-37 [23-25]. In RA patients, IL-37 levels significantly correlated with the rheumatoid factor (RF) value, disease activity, and the levels of IL-4, IL7, IL-10, IL-12, and IL-13. The plasma level of IL-37 is also decreased in those who respond to treatment with diseasemodifying anti-rheumatic drugs (DMARD) [23, 25, 26]. However, the opposing phenomenon is observed in some other diseases. For example, in Behcet's disease (BD), both mRNA and protein expression of IL-37 was significantly reduced in PBMCs from patients with active disease compared to non-diseased individuals [27]. Moreover, decreased production and expression of IL-37 was also noted in re-stimulated PBMCs from children with allergic bronchial asthma $[19,28]$.

Both surface expression and intracellular production of IL-37 increase following stimulation with pro-inflammatory cytokines IL-1 $\beta$, IL-18, TNF- $\alpha$, and IFN- $\gamma$, and antiinflammatory cytokines TGF- $\beta$, IL-10, as well as various toll-like receptor (TLR) ligands [3, 29]. The level of IL-37 in human blood monocytes and DCs rapidly increases under inflammatory conditions, even though it is very low under basal conditions $[3,14,30]$. The inflamed mucosa of IBD patients expressed very high IL-37b levels compared to 
Table 1 The levels of serum IL-37 in different diseased patients

\begin{tabular}{|c|c|c|c|}
\hline Disease & Method and assay & Level in blood/tissue fluid (pg/ml) & Comments \\
\hline $\begin{array}{l}\text { Inflammatory Bowel } \\
\text { Disease (IBD) }\end{array}$ & ELISA (Bio-Swamp) & $\begin{array}{l}\text { Crohn's disease: } 481.67 \pm 232.82(\mathrm{ng} / \mathrm{mL}) ; \\
\text { Ulcerative colitis (UC): } 199.28 \pm 38.60(\mathrm{ng} / \mathrm{mL}) \text {; } \\
\text { Healthy control: } 2275.68 \pm 261.24(\mathrm{ng} / \mathrm{mL}) \text {. } \\
\text { Mild UC: } 346.97 \pm 105.83(\mathrm{ng} / \mathrm{mL}) ; \text { Moderate } \\
\text { UC: } 154.21 \pm 24.95(\mathrm{ng} / \mathrm{mL}) ; \text { Severe UC: } \\
117.75 \pm 17.14(\mathrm{ng} / \mathrm{mL}) \text {. }\end{array}$ & $\begin{array}{l}\text { Serum IL-37 levels are decreased in IBD } \\
\text { patients and also differed significantly } \\
\text { between mild and moderate/severe UC [63]. }\end{array}$ \\
\hline $\begin{array}{l}\text { Proliferative Diabetic } \\
\text { Retinopathy (PDR) }\end{array}$ & ELISA (R\&D Systems) & $\begin{array}{l}\text { In vitreous fluids, } \\
\text { PDR group: } 95.09 \pm 5.22 \\
\text { Control group: } 34.91 \pm 5.61\end{array}$ & $\begin{array}{l}\text { The level of IL-37 is elevated in vitreous } \\
\text { fluids of patients with PDR compared to } \\
\text { controls and correlates with the level of } \\
\text { VEGF-A and Ang-2 [64]. }\end{array}$ \\
\hline Rheumatoid Arthritis (RA) & $\begin{array}{l}\text { ELISA (AdipoGen AG, Liestal, } \\
\text { Switzerland) }\end{array}$ & $\begin{array}{l}\text { RA patients: } 284.7 \pm 151.0, \text { Healthy } \\
\text { control: } 84.64 \pm 36.8 \text {. }\end{array}$ & $\begin{array}{l}\text { Serum IL-37 levels were increased in patients } \\
\text { with RA and were positively associated with } \\
\text { disease activity, IL-17/L-23, and bone loss } \\
\text { in RA [65]. }\end{array}$ \\
\hline $\begin{array}{l}\text { Acute ST-Segment } \\
\text { Elevation Myocardial } \\
\text { Infarction after PCl }\end{array}$ & $\begin{array}{l}\text { ELISA (Adipogen AG, Liestal, } \\
\text { Switzerland) }\end{array}$ & $\begin{array}{l}12 \mathrm{~h} \text { after PCl: } 82.8 \pm 14.79,24 \mathrm{~h} \text { after } \\
\text { PCl: } 82.2 \pm 9.28,48 \mathrm{~h} \text { after PCl: } 84.4 \pm 13.35 \\
\text { Healthy controls: } 120.6 \pm 2.67\end{array}$ & $\begin{array}{l}\text { Plasma and leukocytic IL-37 expression } \\
\text { decreased in patients with acute ST-segment } \\
\text { elevation myocardial infarction after PCl } \\
\text { compared to controls [66]. }\end{array}$ \\
\hline Arterial Calcification & ELISA (Adipogen AG) & $\begin{array}{l}\text { Coronary Artery Calcification (CAC): } \\
72.17 \pm 19.74, \\
\text { Non-coronary artery calcification } \\
\text { (NCAC): } 54.83 \pm 18.63 \text {. } \\
\text { Low-grade CAC: } 61.24 \pm 15.14 \\
\text { Remarkable CAC: } 87.69 \pm 14.42\end{array}$ & $\begin{array}{l}\text { Increased IL-37 concentrations are associated } \\
\text { with the onset of arterial calcification [47]. }\end{array}$ \\
\hline $\begin{array}{l}\text { Systemic Lupus } \\
\text { Erythematosus (SLE) }\end{array}$ & ELISA (R\&D Systems Inc) & $\begin{array}{l}\text { Normal controls: } 10.49(4.90,14.94) \text {, } \\
\text { SLE patients: } 13.63(7.77,18.24)\end{array}$ & $\begin{array}{l}\text { Elevated plasma IL-37 levels are seen in SLE } \\
\text { patients and are associated with anti-Sm, } \\
\text { anti-RNP and C3 [67]. }\end{array}$ \\
\hline Asthma & ELISA (Adipogen AG) & $\begin{array}{l}\text { Asthmatic patients: } 48.15 \pm 8.49 \\
\text { Healthy controls: } 98.59 \pm 21.83 \\
\text { Mild asthma: } 48.15 \pm 8.67 \\
\text { Moderate: } 48.30 \pm 8.53\end{array}$ & $\begin{array}{l}\text { The serum level of } \\
\text { IL-37 in asthmatic patients was significantly } \\
\text { lower compared to healthy controls. There } \\
\text { was no statistically significant difference } \\
\text { between the mild and moderate group [42]. }\end{array}$ \\
\hline Asthma & Real-time quantitative PCR & $\begin{array}{l}\text { The relative expression of } I L-37 \text { mRNA } \\
\text { in asthmatic patients was significantly } \\
\text { lower than in healthy controls }(P=0.0001) \text {. }\end{array}$ & $\begin{array}{l}\text { IL-37 mRNA levels in serum and induced } \\
\text { sputum were significantly lower in asthma } \\
\text { patients compared to healthy controls. [42]. }\end{array}$ \\
\hline
\end{tabular}

Data are expressed as mean \pm SD or median (IQR)

the normal colonic mucosa evaluated by immunohistochemistry, real time-polymerase chain reaction (PCR), and Western blotting [31]. Similar results were also obtained from the epithelial cells and submucosal lymphoid cells of pediatric patients with chronic IBD [32]. Flow cytometry of circulating B cells, active natural killer cells, and monocytes in patients with IBD showed increased production of IL-37 compared to the control group [33]. Interestingly, endogenous glial cells are likely to be the early source of IL-37 in mice spinal cords, while macrophages are the main IL-37expressing cells in IL-37tg mice after several types of inflammatory challenge $[3,30,34]$. This is supported by the low level of leukocyte infiltration at the early stages of the immune response instead of endogenous glial cells [35].

Inflammatory states in general are likely to increase the expression of IL-37. For example, IL-37 expression was found to have a non-independent positive association with viral infection [36]. Furthermore, chronically infected HBV patients with high viral loads had higher serum levels of IL-37 compared to non-infected individuals [37]. Environmental stimuli can also affect the production of IL-37. Di Stefano and colleagues reported that smokers had decreased expression of IL-37 in the submucosa compared with healthy non-smokers [38].

\section{Regulation of leukocyte trafficking and activation Macrophage/monocyte}

As an immune-suppressive factor, IL-37 exerts a vital role in the trafficking of macrophages and monocytes to areas of inflammation. IL-37-expressing transgenic mice exhibited decreased numbers of macrophages and blood-borne neutrophils in comparison to wild-type (WT) mice, along with decreased levels of other cytokines (Fig. 2) [21]. IL-37 can also suppress macrophage production of pro-inflammatory factors. In human blood-derived M1differentiated macrophages that are highly inflammatory, the rIL-37 precursor decreased LPS-induced IL-6 secretion by approximately $50 \%$. Moreover, LPS-induced secretion of IL- 6 , TNF- $\alpha$, and IL-1 $\beta$ are enhanced by administration of a monoclonal anti-IL-37 neutralizing 


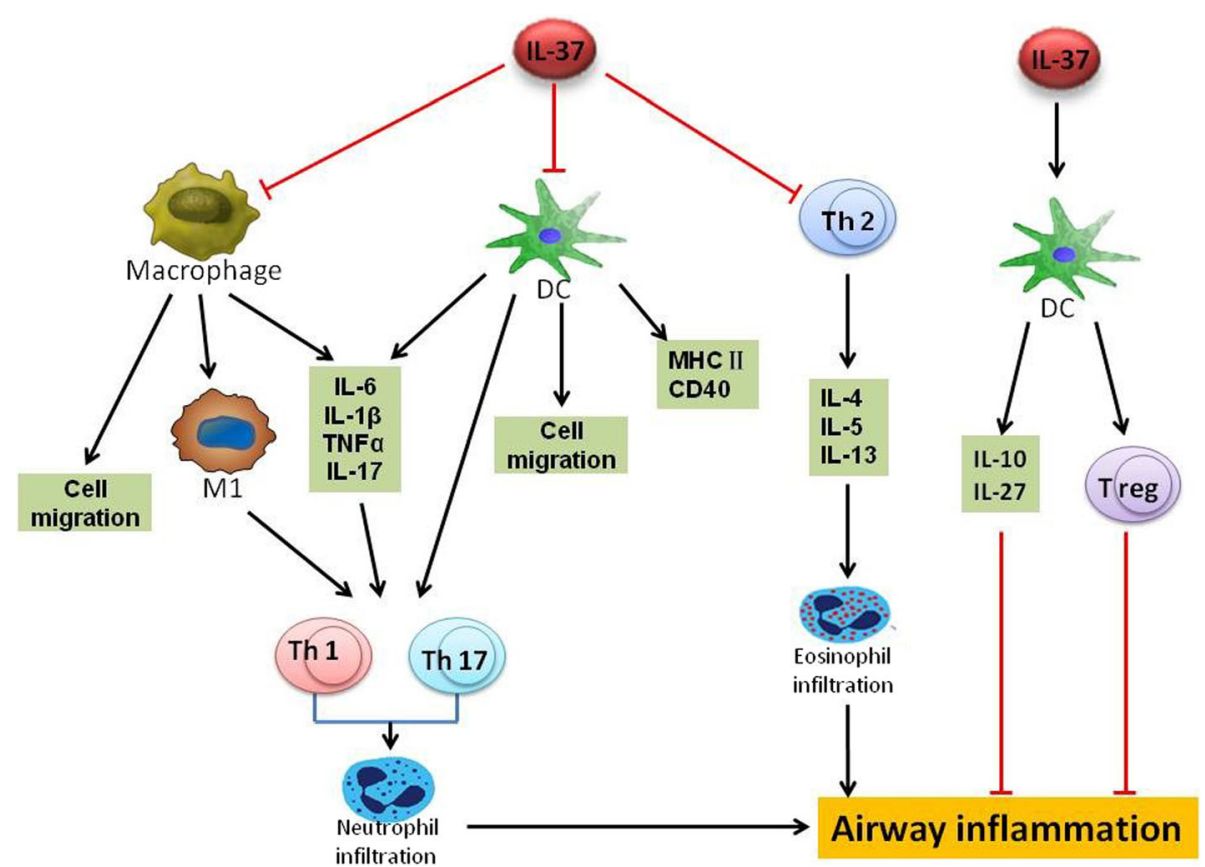

Fig. 2 The function of IL-37 in asthma. The black arrow indicates positive effects, while the red T-shaped lines indicate negative effects. CD: Cluster of differentiation; DC, dendritic cell; IL, interleukin; MHC, major histocompatibility complex; Th, helper T cell; TNF, Tumor necrosis factor; T reg, T regulatory cell

antibody. Mechanistically, IL-37 promotes the increase in IL-1R8 mRNA levels in M1 macrophages, which leads to the dampening of LPS-induced p38 MAPK and pERK, and consequently resulted in anti-inflammatory effects [20]. Similar results were also found in human THP-1 macrophages [39], in those with rheumatoid arthritis [26] and systemic lupus erythematosus [40], in PBMCs of patients with ankylosing spondylitis [41], and in monocytes from human sputum [42]. IL-37 can also modulate macrophage polarity. Huang and colleagues cultured human PBMCs with oxygenated low-density lipoprotein (ox-LDL) to induce M1 macrophages. This process was inhibited by the addition of IL-37 [43].

\section{Neutrophils}

IL-37 can suppress the tissue infiltration of neutrophils. In a murine model of myocardial ischemia/reperfusion (I/ $\mathrm{R})$, neutrophil extravasation was significantly dampened after treatment with IL-37, and the cardiac troponin T level and size of infarction area were reduced, indicating ameliorated I/R injury. Cardiac function also improved. Furthermore, in vitro, IL-37 also inhibited neutrophil migration towards the chemokine LIX [13]. Similarly, reduced cellular infiltration following inflammation in IL-37tg mice revealed the importance of a number of proteins in mediating leukocyte recruitment. In mice with aspergillosis, IL-37 reduced neutrophil recruitment. This process was not dependent on the induction of IL-10 but rather depended on dampened activation of the NLRP3 inflammasome. When NLRP3-deficient mice were subjected to Aspergillus spores, neutrophil recruitment in the bronchoalveolar (BAL) fluid and lungs, and IL- $1 \beta$ production were lower than in wild-type mice. Furthermore, this suppression was not altered by IL-37 treatment [12]. Similarly, IL-37 also reduced neutrophil infiltration in a mouse model of arthritis treated with streptococcal cell wall fragments [44], and in mice with spinal cord injury [21].

\section{Dendritic cells and lymphocytes}

IL-37 also regulates the migratory pattern, maturation, and activation of dendritic cells (DC). In a murine model of skin contact hypersensitivity (CHS), bone marrowderived DCs (BMDCs) isolated from transgenic mice expressing the human IL-37b isoform (IL-37tg) displayed a decreased migratory capacity compared to those from WT mice, although the difference was not statistically significant [14]. IL-37 could also suppress the maturation of DC. LPS-induced MHC II and CD40 expression in BMDCs isolated from IL-37tg mice was reduced by 31 and $52 \%$, respectively, compared to WT mice. DCs isolated from IL-37tg mice also exhibited reduced activation and decreased production of IL-1 $\beta$, IL-6, and IL-12. However, IL-10 secretion increased compared to DCs from WT mice. Furthermore, DCs from IL-37tg mice were tolerogenic and could readily induce $\mathrm{T}$ regulatory (Treg) cell production but had a lower ability to stimulate naive $\mathrm{T}$ 
cells and antigen-specific T cells [14]. Other studies have also demonstrated that IL-37 could reduce maturation of DCs $[3,11]$.

IL-37 produces similar effects in humans as is evidenced by mice models. Upon stimulation with recombinant (r)IL-37, DCs from patients with Behcet's disease (BD) have decreased IL- 6 and IL- $1 \beta$ expression, and increased IL-27 expression. Furthermore, rIL-37 could markedly reduce the production of reactive oxygen species (ROS) and dampen the activation of all three MAPK pathways (ERK1/2, JNK, and p38) in DCs. Th17 and Th1 cell responses were also inhibited in DCs treated with rIL-37. However, rIL-37 did not affect the DC surface markers CD40, CD86, CD80 and HLA-DR, thus its effects are specific [27].

Recombinant IL-37 significantly reduced Th17 cell frequency and the expression of IL-17 in CD4+ T cells and PBMCs from patients with rheumatoid arthritis. Moreover, IL-37 could markedly suppress Th17 cell proliferation, while only slightly affecting Th17 cell differentiation. Administration of adenovirus encoding human IL-37 (Ad-IL-37) to Th17 cells also remarkably decreased the expression of IL-17 and IL-17-driving cytokines in the synovium and joint cells from mice with collagen-induced arthritis (CIA) [45]. A similar result was also found in $\mathrm{CD} 4+\mathrm{T}$ cells from induced sputum in patients with asthma [42].

\section{Other cells}

IL-37 not only interacts with inflammatory or immune cells but also with structural cells such as bronchial epithelial cells and smooth muscle cells, which are also key targets in asthma. In sputum-cultured cells and in bronchial epithelial cultured cells, addition of recombinant IL-37 partially suppressed production of the inflammatory protein thymic stromal lymphopoietin (TSLP) by bronchial epithelial cells [46]. Recent research found that vascular smooth muscle cells were the main source of IL-37 in patients with coronary artery calcification (CAC). However, the exact interaction mechanism is yet to be revealed [47].

\section{IL-37 in experimental models of asthma}

In the murine ovalbumin (OVA) model of allergic asthma, IL-37 has been shown to have remarkable antiinflammatory properties. Eosinophil numbers in BAL and airway tissue are significantly reduced by local administration of IL-37. However, administration of IL-37 did not change the numbers of macrophages, lymphocytes, or neutrophils. Examination of periodic acid Schiff (PAS)-stained airway cross-sections showed that IL-37 markedly reduced goblet cell hyperplasia in the OVAmodel. Moreover, methacholine provocation indicated that IL-37 could also reduce airway hyper-reactivity
(AHR) in asthmatic mice. Treatment of experimental asthma with intranasal rhIL-37 resulted in significantly decreased production of Th2-type cytokines, such as IL4, IL-5, and IL-13 as well as pro-inflammatory cytokines such as IL-6. Furthermore, the anti-inflammatory action of IL-37 depended on IL18Ra as well as the orphan receptor SIGIRR/IL-1R8 [19].

\section{IL-37 in human asthma}

Asthma is characterized by chronic airway inflammation caused by abnormal T-cell responses [48]. The inflammation is finely modulated by CD4+ T lymphocytes, including Th1, Th2, and Th17 cells [49]. The infiltration of inflammatory cells and release of inflammatory factors leads to increased bronchial contractions termed AHR and asthmatic symptoms such as wheezing, shortness of breath, and chest tightness [50].

Asthma is a heterogeneous disease, and increased efforts have been made in sub-typing the different phenotypes of asthma. A common method of sub-typing asthma assesses the presence of different inflammatory cells found in induced sputum. Asthma can thereby be classified into four different groups: eosinophilic asthma, neutrophilic asthma, paucigranulocytic asthma, and mixed granulocytic asthma. Each sub-type responds to therapy differentially due to distinctly different immunological mechanisms [51-53]. Crucial to the development of "personalized medicine" is the recognition that asthma is not one homogenous disease but that different sub-types of asthma exist. Classical eosinophilic asthma is the best-characterized sub-type and involves allergen-induced activation of Th2 pathways and release of Th2 cytokines such as IL-4, IL-5, IL-9, and IL-13 [54]. Eosinophilic asthma responds well to corticosteroids, which are the first-line therapy currently used against asthma. Neutrophilic asthma, on the other hand, is driven by the activation of the innate immune system including TLRs and NLRP3 inflammasomes by infections and environmental pollutants $[55,56]$. This sub-type of asthma is less well-characterized and notoriously resistant to corticosteroid treatment.

IL-37 plays different roles in the pathogenesis of the different phenotypes of asthma. IL-17, which can be suppressed by IL-37 [45], is involved in both neutrophilic and eosinophilic asthma. IL-17 produced by Th17 cells or macrophages not only promotes the infiltration of neutrophils into the lung but recent evidence also suggests that it can contribute to the development of allergic eosinophilic asthma $[57,58]$, where it acts synergistically with Th2 cytokines to promote AHR [57, 59, 60].

IL-37 can suppress Th1, Th2, and Th17 effector responses to modulate inflammatory responses (Fig. 2) [19, 45]. Defective IL-37 signaling can lead to both Th2- and Th1-mediated inflammatory diseases [23, 25, 26], including asthma [19]. 
Despite the sound theoretical possibility, the role of IL-37 in asthma is still not well established. Charrad and colleagues found that IL-37 mRNA expression in serum and induced sputum was significantly lower in asthmatic patients than healthy controls, and that IL-37 mRNA expression was associated with asthma severity [42]. Similar data were reported by Lunding et al., who found significantly lower IL-37 production in human PBMCs from children with allergic asthma compared to healthy controls. Furthermore, treatment of PBMCs with antiCD3/anti-CD28 decreased IL-37 expression in supernatants from asthmatic samples [19]. These results were confirmed by Raedler and colleagues who also found decreased IL-37 expressions in those with allergic asthma compared to healthy controls [28]. A non-allergic asthma group was also included in this study and patients with non-allergic asthma exhibited increased expression of IL-37 compared to those with allergic asthma [28]. Interestingly, recombinant IL-37 has been shown to partially suppress TSLP production in bronchial epithelial cells from asthmatic patients [46]. These contradictory observations from experimental data might be due to the heterogeneity of asthma and explained by the differences in the sub-types of asthma that were studied. Thus, additional studies with carefully phenotyped asthmatic patients are required to fully characterize the expression of IL-37 in asthmatic patients.

\section{Conclusion}

Despite robust evidence showing that IL-37 is an important regulator of inflammatory cell infiltration, activation, and clearance in experimental models, data on the levels and functions of IL-37 in human asthma is still limited. Recent studies using the OVA model of asthma indicate that IL-37 exerts anti-inflammatory effects in vivo and also suppresses allergen-induced AHR. The lack of consistent data in humans might be due to the heterogeneity of asthma. Thus, additional studies with carefully phenotyped asthmatic patients are required to be able to fully characterize the expression of IL-37 in this disease. Targeting the actions of IL-37 might represent a promising strategy for the development of effective therapeutic agents against asthma.

\footnotetext{
Abbreviations

AHR: Airway hyper-reactivity; Ang-2: Angiopoietin; BAL: Bronchoalveolar lavage; BD: Behcet's disease; BMDC: Bone marrow-derived dendritic cells; CAC: Coronary artery calcification; CHS: Contact hypersensitivity; CIA: Collagen-induced arthritis; COPD: Chronic obstructive pulmonary disease; CXC: Chemokine; DC: Dendritic cell; DMARD: Disease-modifying anti-rheumatic drugs; ERK: Extracellular regulated protein kinases; G-CSF: Granulocyte colony-stimulating factor; GM-CSF: Granulocyte-macrophage colony stimulating factor; HIV: Human immunodeficiency virus; HLA: Human leukocyte antigen; IBD: Inflammatory bowel disease; IFN: Interferon; IL: Interleukin; JNK: c-Jun N-terminal kinase; LIX: Lipopolysaccharide-induced; LPS: Lipopolysaccharide; MAPK: Mitogenactivated protein kinase; MHC: Major histocompatibility complex; NCAC: Noncoronary artery calcification; OVA: Ovalbumin; Ox-LDL: Oxygenated low-density
}

lipoprotein; PAS: Periodic acid Schiff; PBMC: Peripheral blood mononuclear cell; PCI: Percutaneous coronary intervention; PCR: Polymerase chain reaction; PDR: Proliferative diabetic retinopathy; Ra: Receptor antagonist; RA: Rheumatoid arthritis; RF: Rheumatoid factor; ROS: Reactive oxygen species; SLE: Systemic lupus erythematosus; Th: Helper T cell; THP: Human acute monocytic leukemia cell line; TLR: Toll-like receptor; TNF: Tumor necrosis factor; Treg: T regulatory cell; UC: Ulcerative colitis; VEGF: Vascular endothelial growth factor; WT: Wild-type

\section{Acknowledgements}

Not applicable.

\begin{abstract}
Funding
This work was funded by the Jilin province science and technology development plan (20150311066YY and 20160101135JC), and the Young Scholars Program of Norman Bethune Health Science Center of Jilin University (2013206036). The design of the study and writing of the manuscript was in accordance with the rules of the funding body.
\end{abstract}

Availability of data and materials

Not applicable.

\section{Authors' contributions}

PG contributed to the conception of the study. JZ and LZ drafted the manuscript. All authors revised the manuscript critically and approved of the final version.

Ethics approval and consent to participate

Not applicable.

\section{Consent for publication}

Not applicable.

\section{Competing interests}

The authors declare that they have no competing interests.

\section{Publisher's Note}

Springer Nature remains neutral with regard to jurisdictional claims in published maps and institutional affiliations.

\section{Author details}

'Department of Respiratory Medicine, The Second Hospital of Jilin University, Changchun, Jilin, China. ${ }^{2}$ Department of Gastroenterology, Changchun Central Hospital, Changchun, Jilin, China.

Received: 30 April 2017 Accepted: 9 November 2017

Published online: 14 November 2017

\section{References}

1. Smith DE, Renshaw BR, Ketchem RR, Kubin M, Garka KE, Sims JE. Four new members expand the interleukin-1 superfamily. J Biol Chem. 2000;275:1169-75.

2. Pan G, Risser P, Mao W, Baldwin DT, Zhong AW, Filvaroff E, et al. IL-1H, an interleukin 1-related protein that binds IL-18 receptor/L-1Rrp. Cytokine. 2001:13:1-7.

3. Nold MF, Nold-Petry CA, Zepp JA, Palmer BE, Bufler P, Dinarello CA. IL-37 is a fundamental inhibitor of innate immunity. Nat Immunol. 2010;11:1014-22.

4. Busfield SJ, Comrack CA, Yu G, Chickering TW, Smutko JS, Zhou H, et al. Identification and gene organization of three novel members of the IL-1 family on human chromosome 2. Genomics. 2000;66:213-6.

5. Tsutsumi N, Kimura T, Arita K, Ariyoshi M, Ohnishi H, Yamamoto T, et al. The structural basis for receptor recognition of human interleukin-18. Nat Commun. 2014;5:5340.

6. Wang M, Wang B, Ma Z, Sun X, Tang Y, Li X, et al. Detection of the novel IL1 family cytokines by QAH-ILIF-1 assay in rheumatoid arthritis. Cell Mol Biol (Noisy-le-grand). 2016;62:31-4.

7. Newman TL, Tuzun E, Morrison VA, Hayden KE, Ventura M, McGrath SD, et al. A genome-wide survey of structural variation between human and chimpanzee. Genome Res. 2005;15:1344-56.

8. Taylor SL, Renshaw BR, Garka KE, Smith DE, Sims JE. Genomic organization of the interleukin-1 locus. Genomics. 2002;79:726-33.

9. Kumar S, Hanning CR, Brigham-Burke MR, Rieman DJ, Lehr R, Khandekar S, et al. Interleukin-1F7B (IL-1H4//L-1F7) is processed by caspase-1 and mature 
IL-1F7B binds to the IL-18 receptor but does not induce IFN-gamma production. Cytokine. 2002;18:61-71.

10. Boraschi D, Lucchesi D, Hainzl S, Leitner M, Maier E, Mangelberger D, et al. IL-37: a new anti-inflammatory cytokine of the IL-1 family. Eur Cytokine Netw. 2011;22:127-47.

11. Nold-Petry CA, Lo CY, Rudloff I, Elgass KD, Li S, Gantier MP, et al. IL-37 requires the receptors IL-18Ralpha and IL-1R8 (SIGIRR) to carry out its multifaceted anti-inflammatory program upon innate signal transduction. Nat Immunol. 2015;16:354-65.

12. Moretti S, Bozza S, Oikonomou V, Renga G, Casagrande A, lannitti RG, et al. IL-37 inhibits inflammasome activation and disease severity in murine aspergillosis. PLoS Pathog. 2014;10:e1004462.

13. Wu B, Meng K, Ji Q, Cheng M, Yu K, Zhao X, et al. Interleukin-37 ameliorates myocardial ischaemia/reperfusion injury in mice. Clin Exp Immunol. 2014; 176:438-51.

14. Luo Y, Cai X, Liu S, Wang S, Nold-Petry CA, Nold MF, et al. Suppression of antigen-specific adaptive immunity by IL-37 via induction of tolerogenic dendritic cells. Proc Natl Acad Sci U S A. 2014;111:15178-83.

15. Gao W, Kumar S, Lotze MT, Hanning C, Robbins PD, Gambotto A. Innate immunity mediated by the cytokine IL-1 homologue 4 (IL-1H4/LL-1F7) induces IL-12-dependent adaptive and profound antitumor immunity. J Immunol. 2003;170:107-13.

16. Bulau AM, Fink M, Maucksch C, Kappler R, Mayr D, Wagner K, et al. In Vivo expression of interleukin-37 reduces local and systemic inflammation in concanavalin A-induced hepatitis. ScientificWorldJournal. 2011;11:2480-90.

17. Bulau AM, Nold MF, Li S, Nold-Petry CA, Fink M, Mansell A, et al. Role of caspase-1 in nuclear translocation of IL-37, release of the cytokine, and IL-37 inhibition of innate immune responses. Proc Natl Acad Sci U S A. 2014;111:2650-5.

18. Yang Y, Zhang ZX, Lian D, Haig A, Bhattacharjee RN, Jevnikar AM. IL-37 inhibits IL-18-induced tubular epithelial cell expression of pro-inflammatory cytokines and renal ischemia-reperfusion injury. Kidney Int. 2015;87:396-408.

19. Lunding L, Webering S, Vock C, Schroder A, Raedler D, Schaub B, et al. IL-37 requires IL-18Ralpha and SIGIRR/IL-1R8 to diminish allergic airway inflammation in mice. Allergy. 2015;70:366-73.

20. Li S, Neff CP, Barber K, Hong J, Luo Y, Azam T, et al. Extracellular forms of IL-37 inhibit innate inflammation in vitro and in vivo but require the IL-1 family decoy receptor IL-1R8. Proc Natl Acad Sci U S A. 2015;112:2497-502.

21. Coll-Miro M, Francos-Quijorna I, Santos-Nogueira E, Torres-Espin A, Bufler P, Dinarello CA, et al. Beneficial effects of IL-37 after spinal cord injury in mice. Proc Natl Acad Sci U S A. 2016;113:1411-6.

22. Hojen JF, Rasmussen $T A$, Andersen KL, Winckelmann AA, Laursen RR, Gunst $J \mathrm{D}$, et al. Interleukin-37 expression is increased in chronic HIV-1-infected individuals and is associated with inflammation and the size of the Total viral reservoir. Mol Med. 2015;21:337-45.

23. Zhao PW, Jiang WG, Wang $L$, Jiang $Z Y$, Shan $Y X$, Jiang $Y F$. Plasma levels of IL-37 and correlation with TNF-alpha, IL-17A, and disease activity during DMARD treatment of rheumatoid arthritis. PLoS One. 2014;9:e95346.

24. Li Y, Wang Z, Yu T, Chen B, Zhang J, Huang K, et al. Increased expression of IL-37 in patients with Graves' disease and its contribution to suppression of proinflammatory cytokines production in peripheral blood mononuclear cells. PLoS One. 2014;9:e107183.

25. Xia L, Shen H, Elevated $\amalg$. Serum and synovial fluid levels of interleukin-37 in patients with rheumatoid arthritis: attenuated the production of inflammatory cytokines. Cytokine. 2015;76:553-7.

26. Xia T, Zheng XF, Qian BH, Fang $H$, Wang JJ, Zhang LL, et al. Plasma Interleukin-37 is elevated in patients with rheumatoid arthritis: its correlation with disease activity and Th1/Th2/Th17-related cytokines. Dis Markers. 2015;2015:795043.

27. Ye Z, Wang C, Kijlstra A, Zhou X, Yang PA. Possible role for interleukin 37 in the pathogenesis of Behcet's disease. Curr Mol Med. 2014;14:535-42.

28. Raedler D, Ballenberger N, Klucker E, Bock A, Otto R, Prazeres da Costa O, et al. Identification of novel immune phenotypes for allergic and nonallergic childhood asthma. J Allergy Clin Immunol. 2015;135:81-91.

29. Bufler P, Gamboni-Robertson F, Azam T, Kim SH, Dinarello CA. Interleukin-1 homologues IL-1F7b and IL-18 contain functional mRNA instability elements within the coding region responsive to lipopolysaccharide. Biochem J. 2004;381:503-10.

30. McNamee EN, Masterson JC, Jedlicka P, McManus M, Grenz A, Collins CB, et al. Interleukin 37 expression protects mice from colitis. Proc Natl Acad Sci U S A. 2011;108:16711-6.
31. Imaeda H, Takahashi K, Fujimoto T, Kasumi E, Ban H, Bamba S, et al. Epithelial expression of interleukin-37b in inflammatory bowel disease. Clin Exp Immunol. 2013;172:410-6.

32. Weidlich S, Bulau AM, Schwerd T, Althans J, Kappler R, Koletzko S, et al. Intestinal expression of the anti-inflammatory interleukin-1 homologue IL-37 in pediatric inflammatory bowel disease. J Pediatr Gastroenterol Nutr. 2014;59:e18-26.

33. Fonseca-Camarillo G, Furuzawa-Carballeda J, Yamamoto-Furusho JK. Interleukin 35 (IL-35) and IL-37: intestinal and peripheral expression by T and $\mathrm{B}$ regulatory cells in patients with inflammatory bowel disease. Cytokine. 2015;75:389-402.

34. Quirk S, Agrawal DK. Immunobiology of IL-37: mechanism of action and clinical perspectives. Expert Rev Clin Immunol. 2014;10:1703-9.

35. David S, Lopez-Vales R, Wee Yong V. Harmful and beneficial effects of inflammation after spinal cord injury: potential therapeutic implications. Handb Clin Neurol. 2012;109:485-502.

36. Jartti T, Palomares $\mathrm{O}$, Waris $\mathrm{M}$, Tastan $\mathrm{O}$, Nieminen R, Puhakka T, et al. Distinct regulation of tonsillar immune response in virus infection. Allergy. 2014;69:658-67.

37. Li C, Ji H, Cai Y, Ayana DA, Lv P, Liu M, et al. Serum interleukin-37 concentrations and HBeAg seroconversion in chronic HBV patients during telbivudine treatment. J Interf Cytokine Res. 2013;33:612-8.

38. Di Stefano A, Caramori G, Barczyk A, Vicari C, Brun P, Zanini A, et al. Innate immunity but not NLRP3 inflammasome activation correlates with severity of stable COPD. Thorax. 2014;69:516-24.

39. Gu J, Gao X, Pan X, Peng X, Li Y, Li M. High-level expression and one-step purification of a soluble recombinant human interleukin-37b in Escherichia Coli. Protein Expr Purif. 2015;108:18-22.

40. Ye L, Ji L, Wen Z, Zhou Y, Hu D, Li Y, et al. IL-37 inhibits the production of inflammatory cytokines in peripheral blood mononuclear cells of patients with systemic lupus erythematosus: its correlation with disease activity. J Transl Med. 2014;12:69.

41. Chen B, Huang K, Ye L, Li Y, Zhang J, Zhang J, et al. Interleukin-37 is increased in ankylosing spondylitis patients and associated with disease activity. J Transl Med. 2015;13:36.

42. Charrad R, Berraies A, Hamdi B, Ammar J, Hamzaoui K, Hamzaoui A. Antiinflammatory activity of IL-37 in asthmatic children: correlation with inflammatory cytokines TNF-alpha, IL-beta, IL-6 and IL-17A. Immunobiology. 2016;221:182-7.

43. Huang J, Hou FL, Zhang AY, Li ZL. Protective effect of the polarity of macrophages regulated by IL-37 on atherosclerosis. Genet Mol Res. 2016;15: gmr.15027616.

44. Cavalli G, Koenders M, Kalabokis V, Kim J, Tan AC, Garlanda C, et al. Treating experimental arthritis with the innate immune inhibitor interleukin-37 reduces joint and systemic inflammation. Rheumatology (Oxford). 2016;55: 2220-9.

45. Ye L, Jiang B, Deng J, Du J, Xiong W, Guan Y, et al. IL-37 alleviates rheumatoid arthritis by suppressing IL-17 and IL-17-triggering cytokine production and limiting Th17 cell proliferation. J Immunol. 2015;194:5110-9.

46. Berraies A, Hamdi B, Ammar J, Hamzaoui K, Hamzaoui A. Increased expression of thymic stromal lymphopoietin in induced sputum from asthmatic children. Immunol Lett. 2016;178:85-91.

47. Yu K, Min X, Lin Y, Huang Y, Huang S, Liu L, et al. Increased IL-37 concentrations in patients with arterial calcification. Clin Chim Acta. 2016;461:19-24.

48. Bateman ED, Hurd SS, Barnes PJ, Bousquet J, Drazen JM, FitzGerald M, et al. Global strategy for asthma management and prevention: GINA executive summary. Eur Respir J. 2008;31:143-78.

49. Kay AB. The role of T lymphocytes in asthma. Chem Immunol Allergy. 2006; 91:59-75.

50. Busse WW, Lemanske RF Jr. Asthma. N Engl J Med. 2001;344:350-62.

51. Barnes PJ. Immunology of asthma and chronic obstructive pulmonary disease. Nat Rev Immunol. 2008:8:183-92.

52. Haldar P, Brightling CE, Hargadon B, Gupta S, Monteiro W, Sousa A, et al. Mepolizumab and exacerbations of refractory eosinophilic asthma. N Engl J Med. 2009;360:973-84.

53. Simpson JL, Scott R, Boyle MJ, Gibson PG. Inflammatory subtypes in asthma: assessment and identification using induced sputum. Respirology. 2006;11:54-61.

54. Woodruff PG, Modrek B, Choy DF, Jia G, Abbas AR, Ellwanger A, et al. Thelper type 2-driven inflammation defines major subphenotypes of asthma. Am J Respir Crit Care Med. 2009;180:388-95.

55. Mortaz E, Masjedi MR, Allameh A, Adcock IM. Inflammasome signaling in pathogenesis of lung diseases. Curr Pharm Des. 2012;18:2320-8. 
56. dos Santos G, Kutuzov MA, Ridge KM. The inflammasome in lung diseases. Am J Physiol Lung Cell Mol Physiol. 2012;303:L627-33.

57. Wilson RH, Whitehead GS, Nakano H, Free ME, Kolls JK, Cook DN. Allergic sensitization through the airway primes Th17-dependent neutrophilia and airway hyperresponsiveness. Am J Respir Crit Care Med. 2009;180:720-30.

58. Barczyk A, Pierzchala W, Sozanska E. Interleukin-17 in sputum correlates with airway hyperresponsiveness to methacholine. Respir Med. 2003;97:726-33.

59. McKinley L, Alcorn JF, Peterson A, Dupont RB, Kapadia S, Logar A, et al. TH17 cells mediate steroid-resistant airway inflammation and airway hyperresponsiveness in mice. J Immunol. 2008;181:4089-97.

60. Wakashin H, Hirose K, Maezawa Y, Kagami S, Suto A, Watanabe N, et al. IL23 and Th17 cells enhance Th2-cell-mediated eosinophilic airway inflammation in mice. Am J Respir Crit Care Med. 2008;178:1023-32.

61. Novick D, Kim S, Kaplanski G, Dinarello CA. Interleukin-18, more than a Th1 cytokine. Semin Immunol. 2013:25:439-48.

62. Dinarello CA, Nold-Petry C, Nold M, Fujita M, Li S, Kim S, et al. Suppression of innate inflammation and immunity by interleukin-37. Eur J Immunol. 2016;46:1067-81.

63. Li Y, Wang Y, Liu Y, Wang Y, Zuo X, Li Y, et al. The possible role of the novel cytokines il-35 and il-37 in inflammatory bowel disease. Mediat Inflamm. 2014;2014:136329.

64. Zhao M, Hu Y, Yu Y, Lin Q, Yang J, SB S, et al. Involvement of IL-37 in the pathogenesis of proliferative diabetic retinopathy. Invest Ophthalmol Vis Sci. 2016:57:2955-62

65. Yang L, Zhang J, Tao J, Elevated LT. Serum levels of Interleukin-37 are associated with inflammatory cytokines and disease activity in rheumatoid arthritis. APMIS. 2015;123:1025-31.

66. Wang X, Cai X, Chen L, Xu D, Li J. The evaluation of plasma and leukocytic IL-37 expression in early inflammation in patients with acute ST-segment elevation myocardial infarction after PCI. Mediat Inflamm. 2015;2015:626934.

67. Wu GC, Li HM, Wang JB, Leng RX, Wang DG, Ye DQ. Elevated plasma interleukin-37 levels in systemic lupus erythematosus patients. Lupus. 2016; 25:1377-80.

\section{Submit your next manuscript to BioMed Central and we will help you at every step:}

- We accept pre-submission inquiries

- Our selector tool helps you to find the most relevant journal

- We provide round the clock customer support

- Convenient online submission

- Thorough peer review

- Inclusion in PubMed and all major indexing services

- Maximum visibility for your research

Submit your manuscript at www.biomedcentral.com/submit

) Biomed Central 